\title{
Analisis Sensorik dengan Model Rasch dan Standarisasi Nilai Gizi Makanan Selingan Berbasis Pangan Lokal
}

\author{
Dedeh$^{1}$, Dewi Marhaeni Diah Herawati², Lulu Eva Rakhmilla² \\ ${ }^{1}$ Instalasi Gizi Rumah Sakit Umum Pusat Dr. Hasan Sadikin Bandung \\ ${ }^{2}$ Departemen Ilmu Kesehatan Masyarakat, Fakultas Kedokteran Universitas Padjadjaran
}

\begin{abstract}
Abstrak
Makanan selingan merupakan bagian dari pemberian makanan selama dirawat. Makanan berfungsi untuk menunjang perbaikan kondisi kesehatan pasien sehingga dibutuhkan variasi supaya tidak membosankan, dapat mengurangi terjadinya sisa makanan dan dapat meningkatkan asupan. Penelitian ini bertujuan menganalisis daya terima makanan selingan berbasis pangan lokal dan menyusun standar nilai gizi makanan selingan yang dihasilkan. Metode penelitian menggunakan pendekatan cross sectional dengan subyek penelitian adalah 17 orang ahli gizi dan 16 orang pasien gagal ginjal kronik yang diambil secara consecutive addmission di instalasi gizi dan di ruang rawat RSUP dr Hasan Sadikin pada bulan Januari 2016. Data kuantitatif hasil uji organoleptik/ sensorik dianalisis dengan Rasch Model dan standarisasi nilai gizi menggunakan software nutrisurvey. Hasil analisis Multi Facet Rasch Measurement menunjukkan dari 12 macam makanan selingan berbasis pangan lokal diperoleh 8 makanan selingan berbasis pangan lokal yang dapat diterima oleh ahli gizi maupun oleh pasien gagal ginjal kronik dari seluruh aspek yang dinilai yaitu rasa,warna/ penampilan, aroma,tekstur dan besar porsi. Hasil analisis uji $t$-independent menunjukkan terdapat perbedaan bermakna uji sensorik makanan selingan berbasis pangan lokal oleh ahli gizi dan oleh pasien gagal ginjal kronik $(p=0,003)$. Nilai kalori makanan selingan ada pada kisaran 95 kkal sampai 125 kkal sehingga dapat digunakan untuk penyediaan snack di rumah sakit.
\end{abstract}

Kata Kunci : Evaluasi sensorik, Pangan lokal, Rasch model

\section{Sensory Analysis with Rasch Model and Nutritional Value Standardization Snack of Local Based Food}

\begin{abstract}
The lack of food intake is one of the main reason why there has been degradation in nutrition supply and health condition of patients with chronic renal failure. Snack is part of food ration offered during treatment which is proposed as a source to get more nutrition and meal variation from, reducing the occurrence of food waste and increasing food intake. The aim of this study is to analyze the impact of local food-based snack and create its nutritional value standard. The research method used cross-sectional study. The subject of this research were 17 nutritionists and 16 patients with chronic renal failure gathered in consecutive admission from Hasan Sadikin Hospital's nutrition installation and inwards in January 2016. The quantitative data in the form of organoleptic test results were analyzed using Rasch model and nutritional value standardization measured using nutrisurvey software. The results of Multi Facet Rasch Measurement (MFRM) showed from 12 kinds of local food-based snack, there were 8 variations acceptable for nutritionists as well as by patients with chronic renal failure. Results of independent t-test analysis showed there were significant differences in the organoleptic test of local food-based snack by nutritionists and patients with chronic renal failure $(p=0.003)$. The calorie value of snack is in the range of 95-125 kcal so it can be used for the provision of snacks in the hospital.
\end{abstract}

Keywords : Local food, Organoleptic test, Rasch model

\author{
Korespondensi: \\ Dedeh \\ Instalasi Gizi Rumah Sakit Umum Pusat Dr. Hasan Sadikin Bandung \\ Jl. Pasteur No. 38 Bandung \\ Mobile : 081221843881 \\ Email :dedehsgz@gmail.com
}




\section{Pendahuluan}

Pelayanan gizi di rumah sakit merupakan bagian dari pemberian terapi kepada pasien sehingga dalam penyediaannya harus sesuai dengan keadaan klinis pasien, status metabolisme serta status gizi pasien. ${ }^{1}$ Keadaan gizi pasien sangat berpengaruh pada proses penyembuhan penyakit, sebaliknya proses perjalanan penyakit dapat berpengaruh terhadap keadaan gizi pasien. Sering terjadi kondisi pasien semakin buruk karena tidak tercukupinya kebutuhan zat gizi untuk perbaikan organ tubuh. ${ }^{2}$ Risiko kurang gizi dapat timbul pada keadaan sakit terutama pada pasien dengan anoreksia, kondisi mulut dan gigi geligi yang buruk, gangguan menelan, penyakit saluran cerna disertai mual, muntah dan diare, infeksi berat, lanjut usia dengan penurunan kesadaran dalam waktu lama dan pasien yang menjalani kemoterapi. Energi yang tidak adekuat, lama hari rawat, penyakit non infeksi dan diet khusus merupakan faktor yang memengaruhi terjadinya malnutrisi. Risiko malnutrisi sangat tinggi pada pasien gagal ginjal kronik terutama yang sudah menjalani hemodialisis. Pada setiap sesi hemodialisis terjadi kehilangan banyak zat gizi. Akumulasi produk hasil metabolisme protein berpotensi menimbulkan mual, muntah bahkan anoreksiayangmenyebabkanasupanmakan pasien ginjal kronik menjadi kurang. Penyelenggaraan makanan di rumah sakit bertujuan menyediakan makanan yang berkualitas sesuai kebutuhan gizi, biaya, aman dan dapat diterima oleh pasien guna mencapai status gizi optimal. Pasien dengan penyakit ginjal kronik sering mengalami malnutrisi sehingga memerlukan asupan zat gizi yang cukup. ${ }^{4.7}$ Penatalaksanaan nutrisi yang baik dapat mengurangi beratnya gejala uremia. Protein yang melebihi kebutuhan akan menyebabkan akumulasi produk hasil metabolisme protein, sebaliknya diet protein yang tidak adekuat akan memicu terjadinya katabolisme cadangan protein dan menyebabkan akumulasi produk-produk sisa yang tidak diekskresikan. ${ }^{6}$

Asupan makan pasien gagal ginjal kronik merupakan permasalahan gizi yang harus diatasi supaya pasien tidak jatuh pada keadaan malnutrisi yang lebih berat. Pada proses asuhan gizi terstandar dapat diketahui masalah gizi (diagnosis gizi) secara individual dan dapat dilakukan intervensi gizi individual yang lebih tepat sesuai masalah dan kondisi pasien. ${ }^{8}$ Intervensi gizi melalui penyediaan makanan yang sesuai dengan kondisi pasien, variasi bahan makanan yang aneka ragam dengan cita rasa yang cocok dengan memanfaatkan pangan lokal, diharapkan dapat meningkatkan asupan makanan dan memperbaiki status gizi bagi pasien gagal ginjal kronik.
Singkong, Ubi Cilembu dan jagung manis adalah pangan lokal yang banyak terdapat di Jawa Barat, mudah diperoleh dan harganya cukup terjangkau. Dalam upaya mencapai tujuan pelayanan makanan di rumah sakit, kegiatan penelitian dan pengembangan gizi terapan terus diupayakan dengan menggunakan sarana, fasilitas dan dana yang tersedia. Penelitian dan pengembangan dapat dilakukan khusus dalam lingkup pelayanan gizi terutama teknologi, penyederhanaan dan cara kerja serta penilaian hasil kerja yang dicapai. ${ }^{2}$ Hasil penelitian menyatakan bahwa sisa makanan yang berasal dari menu diet yang diberikan kepada pasien cukup tinggi. ${ }^{1}$ Penyediaan makanan di rumah sakit terdiri dari 3 kali makanan utama dan 2 kali makanan selingan dengan alokasi makanan selingan sebanyak 20$25 \%$ dari kebutuhan. Makanan selingan disajikan diantara waktu penyajian makanan utama yaitu sekitar pukul 10.00 siang dan pukul 15.00 sore. $^{2}$ Hasil penelitian sebelumnya menyatakan bahwa pasien merasa bosan dengan makanan selingan yang disajikan dan masih terjadi sisa makanan. ${ }^{7}$

Penelitian ini membuat aneka makanan selingan berbasis pangan lokal yang dilakukan standarisasi nilai gizi dan penilaian organoleptik atau penilaian sensorik untuk menyediakan variasi makanan selingan yang disajikan di rumah sakit dan menyelaraskan dengan anjuran pemanfaatan pangan lokal di Jawa Barat. Penilaian mutu atau analisa sifat-sifat sensorik dinilai melalui alat indera manusia, evaluasi dikatakan evaluasi sensorik atau organoleptik, manusia yang bertindak sebagai instrumen bertugas menilai sifat atau mutu berdasarkan kesan subjektif. ${ }^{9}$ Karakteristik sensorik makanan berupa penampilan, warna, rasa, tekstur dinilai oleh alat indera manusia dengan mengukur, menganalisis dan menafsirkan kualitas makanan seperti yang dirasakan oleh indera penglihatan, rasa maupun sentuhan. Kualitas keseluruhan makanan tergantung dari atribut gizi dan kualitas sensorik. ${ }^{10}$

Penelitian ini memiliki tujuan mengetahui daya terima makanan selingan yang dibuat dari sudut penilai ahli gizi dan dari sudut penilai pasien gagal ginjal kronik. Makanan selingan yang dibuat dihitung komposisi zat gizi makro dan mikronutriennya agar sesuai dengan standar nilai gizi yang sudah ditentukan dan aman untuk dikonsumsi.

\section{Metode}

Penelitian ini merupakan jenis penelitian observasional analitik dengan rancangan cross sectional dan pemilihan subjek dengan cara 
consecutive admission yaitu ahli gizi dan pasien yang ada pada hari dilaksanakannya analisis sensorik makanan selingan. Diperoleh ahli gizi sebanyak 17 orang dan pasien gagal ginjal kronik yang dirawat sebanyak 16 orang. Subjek penelitian yang memenuhi kriteria inklusi adalah ahli gizi yang sehat dan tidak mengalami gangguan indera pengecap dan pasien gagal ginjal kronik hemodialisis. Penelitian dilaksanakan di RSUP Dr. Hasan Sadikin Bandung pada bulan Januari 2016 dengan memperhatikan aspek etik sesuai dengan hasil kelayakan etik dari Komite Etik Penelitian Kesehatan Fakultas Kedokteran Unpad Bandung No: 020/UN6.C1.3.2/KEPK/ PN/2016 dan mendapatkan izin dari Direktur Utama RSUP DR Hasan Sadikin Bandung No:LB.02.01/C02/2091/II/2016.

Peneliti melakukan ujicoba resep makanan selingan berbasis pangan lokal kemudian disajikan untuk dinilai oleh subjek dengan mengisi formulir uji organoleptik/ uji sensorik dengan skala hedonik. Panelis mengemukakan tanggapan pribadi suka atau tidak suka, disamping itu juga mengungkapkan tingkat kesukaannya. Tingkat kesukaan disebut juga skala hedonik. Skala hedonik ditransformasikan ke dalam skala numerik dengan angka menurut tingkat kesukaan terhadap aspek yang dinilai (butir aitem). Skala hedonik yang digunakan 1 sampai $7: 1$. Sangat tidak suka, 2. Tidak Suka, 3. Agak tidak suka, 4. Agak suka, 5. Suka, 6. Sangat suka, 7. Amat sangat suka. Aspek yang dinilai oleh panelis ahli gizi meliputi besar porsi, warna, rasa, aroma dan tekstur. Aspek yang dinilai oleh panelis pasien gagal ginjal kronik meliputi rasa, warna/ penampilan dan besar porsi.

Data hasil uji sensorik ini dianalisis dengan Multi Facet Rasch Measurement (MFRM) dan nilai logit diuji dengan uji t-independent. MFRM berupa analisis penilaian majemuk (multi rater) dengan software Facet Versi 3.73. Analisis penilaian majemuk merupakan suatu metode pengukuran untuk mendapatkan pengukuran linier dan pengamatan respons kategori dari penilai yang beragam dengan menggunakan instrument penilaian yang sama. Model Rasch dapat digunakan pada jenis tes bersifat multiaspek (multifacets), yaitu interaksi antara makanan selingan berbasis pangan lokal (yang dinilai/ratee) dengan butir (aspek yang dinilai), dan panelis (rater). ${ }^{11}$ Standarisasi nilai gizi dibuat dengan cara menghitung komposisi nilai gizi makro dan mikronutrien menggunakan software Nutrisurvey.

Makanan selingan berbasis pangan lokal yang dinilai (ratee) sebanyak 12 jenis yang terdiri dari makanan selingan berbahan dasar singkong, jagung manis dan Ubi Cilembu. Makanan selingan berbasis singkong terdiri dari pie singkong, bika singkong, cassava cake dan lapis singkong. Makanan selingan berbasis jagung manis terdiri dari kue jagung imut, nagasari jagung manis, puding jagung susu dan bingka jagung. Makanan selingan berbasis Ubi Cilembu terdiri dari martabak ubi, ubi pelangi, bingka Ubi Cilembu dan kue lumpur ubi.

\section{Hasil}

Tabel 1 Karakteristik Panelis

\begin{tabular}{lccc}
\hline & $\begin{array}{c}\text { Ahli Gizi } \\
(\mathrm{n}=17)\end{array}$ & $\begin{array}{c}\text { Pasien Gagal } \\
\text { Ginjal } \\
(\mathrm{n}=16)\end{array}$ & \\
\hline Laki-laki & 2 & 9 & $33.37 \%$ \\
Perempuan & 15 & 7 & $66.66 \%$ \\
18 - 35 Tahun & 5 & 3 & $24.24 \%$ \\
36 - 55 Tahun & 8 & 5 & $39.39 \%$ \\
55 - 72 Tahun & 4 & 8 & $36.36 \%$ \\
\hline
\end{tabular}

Subjek penilai makanan selingan berbasis pangan lokal adalah ahli gizi dan pasien gagal ginjal kronik sebanyak 33 dan didominasi oleh wanita sebanyak 22 orang dengan rentang usia terbanyak 36 sampai 55 tahun.

Standar nilai kalori makanan selingan di rumah sakit berkisar $95 \mathrm{kkal}$ sampai $125 \mathrm{kkal}$ dan hasil perhitungan dengan software nutrisurvey diperoleh kandungan kalori makanan selingan berbasis pangan lokal berkisar 96 sampai 107.3 kkal. Semua makanan selingan memiliki kandungan nilai gizi yang cukup untuk ukuran porsi makanan selingan baik makronutrien maupun mikronutrien dan masih memenuhi standar yang ditetapkan.

Pada gambar 1A sebaran peta wright ahli gizi diketahui bahwa nilai rata-rata logit makanan selingan dan aspek yang dinilai yaitu $(+0,00$ logit), rata-rata nilai logit ahli gizi yaitu $(-2,33$ logit). Selengkapnya dapat dijelaskan di bawah ini: ${ }^{13}$

Kolom Makanan Selingan dan Aspek yang dinilai: terdapat 6 makanan selingan lokal $(50 \%)$ yang memiliki nilai di atas rata-rata logit yaitu, "bingka singkong, lapis pelangi, lumpur ubi, bingka jagung, marubi dan bingka ubi". Berdasarkan penilaian panelis jenis makanan tersebut dapat diterima dari aspek-aspek yang dinilai yaitu aspek rasa, warna, aroma, tekstur dan besar porsi. Terdapat 6 makanan selingan lokal $(50 \%)$ yang memiliki nilai di bawah ratarata logit yaitu, "cassava, lapis, nagasari, puding jagung susu, pie, dan jagung imut”. Makanan 
Tabel 2 Standar Nilai Gizi per Porsi Makanan Selingan Berbasis Pangan Lokal

\begin{tabular}{llccccccccc}
\hline \multirow{2}{*}{ No } & Nama Makanan & & \multicolumn{8}{c}{ Nilai Gizi per Porsi } \\
& Selingan & $\mathrm{E}$ & $\mathrm{P}$ & $\mathrm{L}$ & $\mathrm{Kh}$ & $\mathrm{So}$ & $\mathrm{K}$ & $\mathrm{Ca}$ & $\mathrm{P}$ & $\mathrm{Fe}$ \\
\hline & & kcal & gram & gram & gram & mgram & mgram & mgram & mgram & mgram \\
1 & Pie Singkong & 103.3 & 2.17 & 4.44 & 14.1 & 28.16 & 135.02 & 28.04 & 59.62 & 0.52 \\
2 & Bika Singong & 102 & 1.06 & 5.54 & 12.73 & 17.66 & 84.33 & 13.72 & 33.05 & 0.35 \\
3 & Cassava Cake & 101.7 & 0.86 & 5.34 & 13.35 & 6.44 & 63.97 & 6.96 & 24.97 & 0.25 \\
4 & Lapis Singkong & 103.7 & 0.67 & 1.81 & 22.06 & 1.97 & 128.36 & 9.43 & 37.68 & 0.49 \\
5 & Kue Jagung Inut & 99.4 & 3.02 & 2 & 17.72 & 23.74 & 58.85 & 19.07 & 48.87 & 0.31 \\
6 & Nagasari Jagung & 99.5 & 0.56 & 1.07 & 22.7 & 3.63 & 43.14 & 0.94 & 18.07 & 2 \\
7 & Puding Jagung Susu & 100.5 & 1.4 & 1.4 & 21.53 & 23.01 & 95.53 & 70.01 & 48.61 & 0.25 \\
8 & Bingka Jagung & 101.5 & 2.11 & 3.65 & 15.77 & 10.5 & 60.32 & 5.1 & 36.04 & 0.34 \\
9 & Marubi & 96 & 5.25 & 0.02 & 24.32 & 8.32 & 145.8 & 18.7 & 14.87 & 0.55 \\
10 & Ubi Pelangi & 107.3 & 2.65 & 2.85 & 18.42 & 40.52 & 149.5 & 84.98 & 73.27 & 0.2 \\
11 & Bingka Ubi & 100.6 & 1.8 & 2.65 & 17.78 & 8.62 & 71.55 & 6.01 & 26.65 & 0.34 \\
& Cilembu & & & & & & & & & \\
12 & Lumpur ubi & 98.18 & 1.91 & 4.72 & 12.41 & 16.31 & 81 & 0 & 29.5 & 0.39 \\
& Rata-rata & 101.14 & 1.95 & 2.95 & 17.74 & 15.74 & 93.11 & 22.1 & 37.6 & 0.4 \\
\hline
\end{tabular}

A. Sebaran Peta Wright Analysis Sensorik Menurut Ahli Gizi

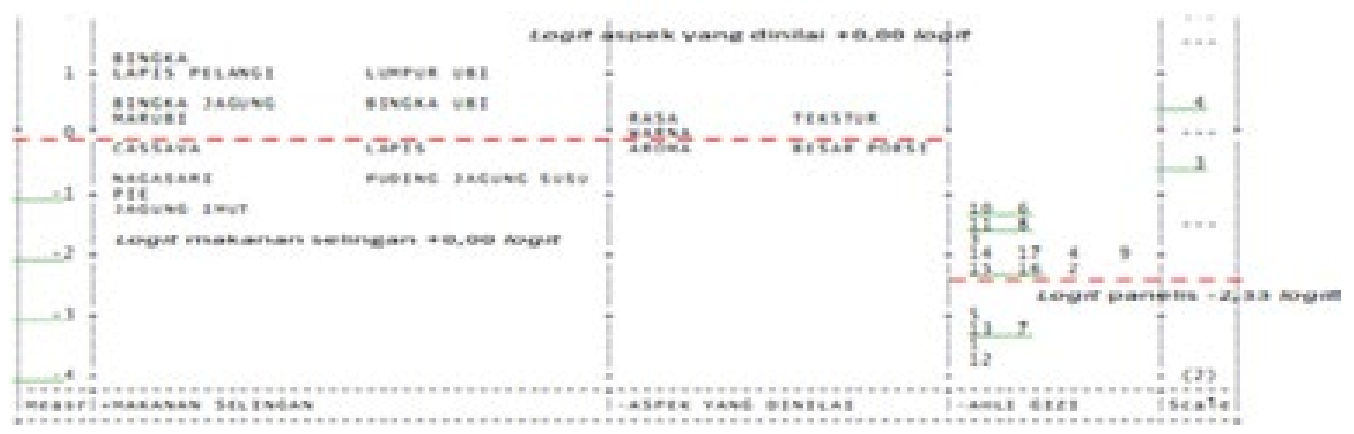

B. Sebaran Peta Wright Analysis Sensorik Menurut Pasien Gagal Ginjal Kronik

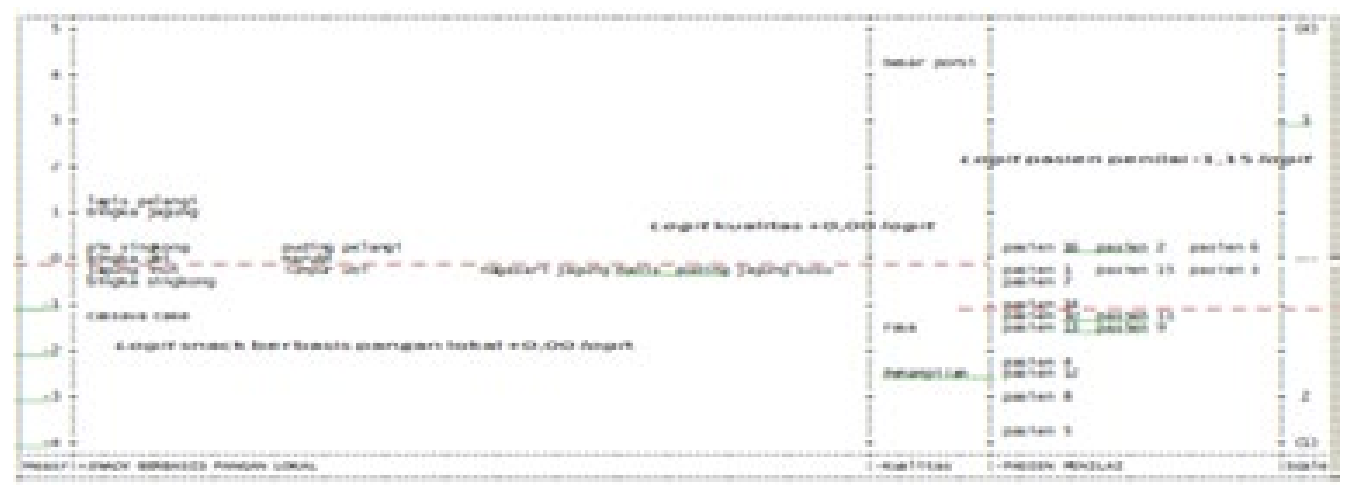

Gambar 1 Sebaran Peta Wright Analysis Sensorik Menurut Ahli Gizi dan Pasien 
selingan cassava dan lapis hanya diterima dari aspek aroma dan besar porsi saja. Terdapat empat jenis makanan yaitu "nagasari jagung manis, pie singkong, jagung imut dan puding jagung susu" merupakan makanan selingan yang belum bisa diterima dari seluruh aspek penilaian. Dapat disimpulkan bahwa ke-4 makanan tersebut tidak direkomendasikan untuk pasien yang mengalami gagal ginjal berdasarkan penilaian oleh ahli gizi;

Kolom Ahli Gizi: terdapat 12 orang ahli gizi yang berada di atas rata-rata nilai logit yaitu ahli gizi dengan kode nomor " $2,16,15,9,4$, 17, 14, 3, 8, 11, 6, dan 10". Ahli gizi tersebut merupakan panelis yang cenderung ketat dalam memberikan penilaian untuk jenis makanan lokal dan aspek yang dinilai pada makanan tersebut. Terdapat 5 orang ahli gizi yang berada di bawah rata-rata nilai logit dengan kode nomor " $12,1,7$, 13, dan 5". Ahli gizi tersebut merupakan panelis yang mudah dalam memberikan penilaian untuk jenis makanan lokal dan aspek yang dinilai pada makanan tersebut. Apabila dibandingkan dengan nilai rata-rata logit pada kolom makanan selingan dan aspek yang dinilai, rata-rata logit ahli gizi berada di bawah rata-rata nilai logit kolom tersebut. Hal ini dapat diartikan bahwa seluruh ahli gizi menyetujui dengan jenis makanan selingan yang diberikan kepada pasien gagal ginjal kronik.

Pada gambar 1B. peta wright menurut pasien gagal ginjal kronik di atas terlihat bahwa nilai rata-rata logit makanan selingan berbasis pangan lokal dan kualitas yaitu $(+0,00$ logit), sedangkan nilai rata-rata logit pada pasien penilai yaitu $(-1,15$ logit $)$. Berdasarkan penilaian pasien dapat disimpulkan bahwa snack berbasis pangan lokal menurut aspek kualitas pangannya dapat diterima oleh pasien yang menderita gagal ginjal kronik. Selengkapnya dapat dijelaskan pada keterangan di bawah ini:

Kolom snack berbasis pangan lokal dan kualitas: terdapat 6 jenis makanan $(50 \%)$ yang berada di atas rata-rata nilai logit yaitu "lapis pelangi, bingka jagung, pie singkong, puding pelangi, bingka ubi, dan marubi". Terdapat 6 jenis makanan $(50 \%)$ yaitu "jagung imut, lumpur ubi, nagasari jagung manis, puding jagung susu, bingka singkong, dan cassava cake" yang berada di bawah rata-rata nilai logit.
Berdasarkan penilaian pasien makanan tersebut memenuhi aspek kualitas pangan yang terdiri dari penampilan dan rasa. Hasil penilaian pasien yang sangat menonjol adalah aspek kualitas besar porsi pada seluruh jenis snack berbasis makanan lokal dengan nilai logit paling tinggi yaitu $(+4,16$ logit $)$, dapat diartikan bahwa besar porsi pada seluruh makanan tersebut sulit untuk disetujui karena kurang sesuai dengan yang diharapkan oleh pasien. Aspek kualitas makanan pada penampilan dan rasa dapat disetujui oleh seluruh pasien yang mengalami gagal ginjal kronik. Jenis makanan "lapis pelangi dan bingka jagung" merupakan makanan paling disukai oleh pasien;

Kolom Pasien Penilai: terdapat 8 pasien $(50 \%)$ yang berada di atas rata-rata nilai logit yaitu "pasien 16, pasien 2, pasien 6 , pasien 1 , pasien 15 , pasien 3 , pasien 7 , dan pasien 14". Hanya terdapat 7 pasien yang tidak menyukai jenis makanan "cassava cake", dan terdapat 8 pasien $(50 \%)$ yang berada di bawah rata-rata nilai logit yaitu "pasien 10 , pasien 11 , pasien 13 , pasien 9 , pasien 4 , pasien 12 , pasien 8 , dan pasien 5 ".

Hasil analisis statistik dengan memasukan nilai logit rasch model kedalam program komputer dengan uji t-independent diperoleh nilai $\mathrm{p}$ sebesar 0.003 yang berarti memiliki perbedaan bermakna antara ahli gizi dan pasien gagal ginjal kronik karena nilai $\mathrm{p}<0.005$.

Model Rasch melalui analisis unexpected respon menilai respon para panelis terhadap aspek-aspek yang dinilai untuk besar porsi, tekstur, warna, rasa dan aroma yang dapat dilihat lebih jelas pada tabel 4.

Pie singkong, puding jagung susu, jagung imut dan nagasari jagung manis merupakan makanan selingan yang paling susah untuk dinilai oleh panelis karena paling banyak memunculkan unexpected response dari panelis. Pada makanan selingan tersebut terdapat aspek penilaian yang kurang bisa diterima oleh kedua panelis. Lapis singkong pelangi merupakan makanan selingan yang sangat mudah dinilai baik oleh ahli gizi maupun oleh pasien karena paling sedikit memunculkan unexpected response. Aspek aroma merupakan aspek yang sulit untuk disetujui/dinilai oleh ahli gizi dan aspek warna adalah hal yang paling mudah untuk diberikan penilaian. Pasien gagal ginjal sangat sulit untuk

Tabel 3 Penilaian Uji Sensorik oleh Ahli Gizi dan Pasien Gagal Ginjal Kronik

\begin{tabular}{lllllll}
\hline & Kelompok & $\mathrm{N}$ & Mean & $\begin{array}{l}\text { Std. } \\
\text { Deviation }\end{array}$ & $\begin{array}{l}\text { Std. Error } \\
\text { Mean }\end{array}$ & T hitung \\
\hline Nilai & Ahli Gizi & 17 & -2.3306 & .76812 & .18630 & \\
& Pasien & 16 & -1.1850 & 1.19118 & .29780 & 0.003 \\
\hline
\end{tabular}


Tabel 4 Distribusi Frekuensi Unexpected Respons terhadap Aspek Penilaian

\begin{tabular}{|c|c|c|c|c|c|c|c|c|c|c|}
\hline \multirow[t]{2}{*}{ No } & \multirow[t]{2}{*}{ Makanan Selingan } & \multicolumn{4}{|c|}{$\begin{array}{l}\text { Aspek Penilaian } \\
\text { Ahli Gizi }\end{array}$} & \multicolumn{5}{|c|}{$\begin{array}{l}\text { Aspek Penilaian } \\
\text { Pasien }\end{array}$} \\
\hline & & $\mathrm{P}$ & $\mathrm{T}$ & $\mathrm{R}$ & $\mathrm{W}$ & A & $\mathrm{P}$ & $\mathrm{R}$ & $\mathrm{W}$ & A \\
\hline 1 & Cassava cake & & & 1 & & 1 & & & 1 & 3 \\
\hline 2 & Bingka singkong & 1 & & & & 1 & 1 & 2 & & 5 \\
\hline 3 & Pai singkong & 1 & 1 & 1 & & 2 & & 3 & 1 & 9 \\
\hline 4 & Lapis singkong Pelangi & & & 1 & & & 1 & & & 2 \\
\hline 5 & Bingka ubi & & 2 & & & 1 & 1 & & & 4 \\
\hline 6 & Lumpur ubi & & & 1 & & & 2 & 2 & & 5 \\
\hline 7 & Marubi & 2 & & & & 1 & 1 & & 1 & 5 \\
\hline 8 & Ubi pelangi & & & 1 & & 2 & & 1 & 1 & 5 \\
\hline 9 & Jagung imut & 2 & & & 2 & & & 2 & & 6 \\
\hline 10 & Nagasari jagung manis & 1 & 2 & 1 & 1 & & & & 1 & 6 \\
\hline 11 & Bingka jagung & 2 & & & & & 1 & & 1 & 4 \\
\hline \multirow[t]{2}{*}{12} & Puding jagung susu & & 2 & 1 & 2 & 2 & & & & 7 \\
\hline & Jumlah & 9 & 7 & 7 & 5 & 10 & 7 & 10 & 6 & \\
\hline
\end{tabular}

Keterangan : P besar porsi, T tekstur, R rasa, W warna, A aroma

menilai aspek rasa dan mudah untuk menilai aspek warna. Dari sebaran respon ahli gizi yang memberikan penilaian terhadap makanan selingan diketahui bahwa hampir semua panelis memberikan nilai yang unexpected dari yang seharusnya dan hanya terdapat 2 panelis ahli gizi yaitu panelis 8 dan panelis 17 yang cenderung menerapkan standar yang sama dalam melakukan penilaian dan objektif, sedangkan panelis yang lain memiliki kecenderungan kurang konsisten dalam menilai makanan selingan terutama panelis ahli gizi no 9 yang paling banyak muncul unexpected respons. Hal ini ditandai dengan tidak munculnya unexpected respons dari kedua panelis tersebut. Panelis dari pasien gagal ginjal kronik yang dapat dikatakan konsisten dalam menilai makanan selingan adalah pasien no 5, 8, 10, 14 dan 15 karena tidak muncul dalam unexpected respons, sebaliknya untuk pasien no 1 dapat dikatakan sebagai pasien yang paling tidak konsisten dalam menilai karena banyak muncul pada unexpected respons. Dari analisis di atas diperoleh 8 makanan selingan berbasis pangan lokal yang dapat diterima oleh panelis ahli gizi maupun panelis pasien gagal ginjal kronik seperti tampak pada gambar 2 .
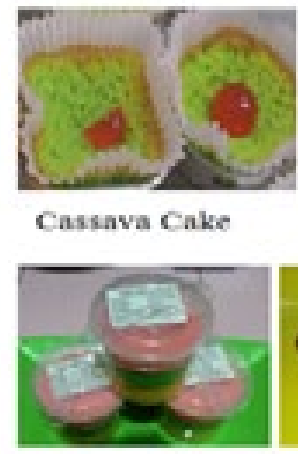

tbi Pelangi

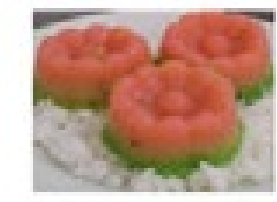

t.apis Pelangi

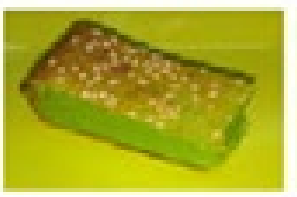

Bingka Jagung

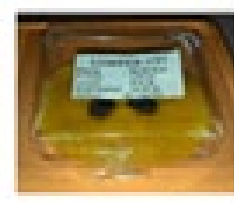

I.umpur toi

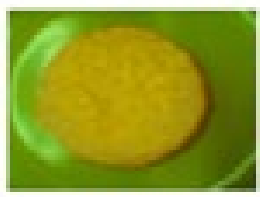

Bingka singkong

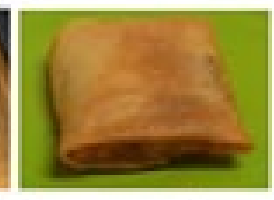

Marubi

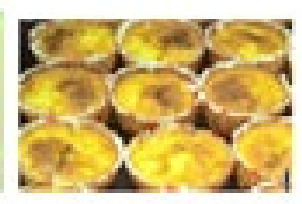

Bingka Ubi

Gambar 2 Makanan Selingan Berbasis Pangan Lokal yang diterima oleh Panelis 


\section{Pembahasan}

Hasil penelitian menunjukkan bahwa terdapat respon yang berbeda dalam menilai kualitas makanan selingan berbasis pangan lokal melalui uji sensorik /organoleptik pada aspek rasa, aroma, besar porsi, tekstur dan warna. Angka logit Rasch model dianalisis dengan program komputer uji $t$-independet diperoleh nilai $\mathrm{p}=0.003(\mathrm{p}<0.005)$ yang berarti memiliki perbedaan bermakna hasil penilaian oleh ahli gizi dan oleh pasien gagal ginjal kronik. Hal ini dapat terjadi karena ahli gizi memiliki kompetensi untuk menilai makanan selingan dan memiliki pengalaman terkait penilaian kualitas makanan, sehingga dengan mudah menilai aspek-aspek tersebut walaupun masih ada penilai/rater yang belum konsisten Kemungkinan rater memiliki masalah generosity error ${ }^{15}$ artinya rater cenderung memberi nilai yang tinggi-tinggi, walaupun kenyataan yang sebenarnya organoleptik snack yang dinilai tidak baik atau sebaliknya. Masalah lain adalah adanya kemungkinan terjadinya subyektifitas rater sehingga sukar baginya untuk memberi nilai yang obyektif.

Perbedaan penilaian sangat mungkin terjadi terkait karakteristik panelis yang memiliki latar belakang dan kondisi berbeda, ahli gizi merupakan orang sehat dan pasien gagal ginjal sedang bermasalah dengan kondisi kesehatannya. Ahli gizi mempunyai latar belakang pendidikan terkait gizi dan makanan sedangkan pasien gagal ginjal pada umumnya memiliki latar belakang pendidikan umum. Panelis ahli gizi dapat dipengaruhi oleh banyak faktor dalam memberikan penilaian yang konsisten dan objektif yaitu tergantung keterampilan, masa kerja dan pengalaman ahli gizi yang bersangkutan. Pasien gagal ginjal dalam keadaan terganggu kesehatannya dan cenderung memiliki sensitifitas yang kurang baik terkait cita rasa bekaitan dengan kondisi sakitnya sehingga objektifitas mengalami masalah dan muncul subjektifitas yang dipengaruhi kondisinya yang berbedabeda. Pasien hemodialisis mengalami akumulasi amonia yang mungkin dapat mengiritasi mukosa mulut sehingga terjadi peradangan mukosa mulut yang akan mempengaruhi persepsi terhadap rasa dan asupan makanan. ${ }^{14}$

Kemampuan memberikan kesan dapat dibedakan berdasarkan kemampuan alat indera memberikan reaksi atas rangsangan yang diterima. Kemampuan tersebut meliputi kemampuan mendeteksi (detection), mengenali (recognition), membedakan (discrimination), membandingkan (scalling) dan kemampuan menyatakan suka atau tidak suka (hedonik). ${ }^{12}$ Perbedaan kemampuan tersebut tidak begitu jelas pada panelis. Sangat sulit untuk dinyatakan bahwa satu kemampuan sensorik lebih penting dan lebih berbeda-beda, dari yang paling mudah hingga sulit atau dari yang paling sederhana sampai yang kompleks (rumit). Faktor lain yang mungkin menyulitkan penilaian adalah karena tidak adanya definisi operasional dari tiap aspek penilaian yang dapat membantu panelis untuk menuangkan kesannya.

Menurut analisis Rasch model pada peta wright unexpected respons diketahui bahwa aspek yang paling sulit dinilai oleh ahli gizi adalah aspek aroma dan yang sulit dinilai oleh pasien adalah aspek rasa, sedangkan aspek warna merupakan aspek yang mudah untuk dinilai oleh kedua panelis. Penentuan makanan selingan yang memiliki daya terima yang baik berdasarkan produk yang paling disukai oleh panelis dibandingkan dengan produk lainnya. ${ }^{12}$ Makanan selingan berupa 12 snack pangan lokal yang diujikan terdapat 4 snack yang menurut kedua panelis ahli gizi maupun panelis pasien gagal ginjal tidak memenuhi penilaian dari semua aspek menurut hasil analisa dengan Rasch model yaitu pie singkong, jagung imut, nagasari jagung manis dan puding jagung susu. Snack yang dapat diterima dari semua aspek yang dinilai oleh kedua panelis ada 4 sanck juga yaitu lapis pelangi, bingka jagung, marubi dan bingka ubi. Sedangkan 4 snack yang lain yaitu bingka singkong, lumpur ubi, pie singkong dan puding ubi pelangi masih bisa diterima oleh sebagian panelis.

Keterbatasan penelitian ini adalah belum menggunakan panelis pasien dengan penyakit lainnya serta tidak dilakukan randomisasi.

Simpulannya makanan selingan berbasis pangan lokal yang dapat diterima menurut panelis dari aspek yang dinilai sebanyak 8 jenis makanan selingan yaitu cassava cake, lapis pelangi, lumur ubi, marubi, ubi pelangi, bingka jagung, bingka singkong dan bingka ubi. Semua makanan selingan berbasis pangan lokal memiliki kandungan kalori dan komposisi zat gizi yang sesuai dengan standar dan aman dikonsumsi.

Manfaat bagi institusi rumah sakit khususnya bagi intsalasi gizi, makanan selingan berbasis pangan lokal dapat dijadikan alternatif penyediaan makanan selingan di rumah sakit dan dapat dijadikan media edukasi agar pasien dapat mengolah sendiri makanan selingan tersebut dan dapat dilaksanakan penelitian daya terima makanan selingan berbasis pangan lokal pada pasien secara lebih meluas

\section{Daftar Pustaka}

1. Dewi Marhaeni. Peran Mutu Katering Dalam Mengatasi Malnutrisi Di Rumah Sakit. 
CelticsPress. 2015; hlm. 7

2. Kementrian Kesehatan RI.,Pedoman Pelayanan Gizi Rumah Sakit.2013; hal 7.41

3. Mahan L.L. \& Stump,S.E. Krause's Food, Nutrition, \& Diet Therapy., USA : W.B.Saunders Company, edisi ke 11. 2000

4. Persatuan Ahli Gizi(PERSAGI) \& Asosiasi Dietesien Indonesia (AsDI).Proses Asuhan Gizi Terstandar. Jakarta.2011

5. Sukandar. Nefrologi Klinik. Edisi IV. Pusat Informasi Dpartemen Ilmu Penyakit Dalam. FK Unpad. Bandung. 2013. hal 632-635

6. Nikolaos Katsilambros. Asuhan Gizi Klinik. Penerbit Buku Kedokteran.Jakarta.2011.hal 135-136

7. Shalabia E, Amal M, Madeha A. Nutritional Status and Malnutrition Prevalence Among Maintanance Hemodialysis Patient. IOSR. JNHS. 2015

8. Bhavana Shailendranath,Ushadevi,Pras hant G. Kedlaya. Sensory Evaluation of Developed Food Products for Hemodialysis Patient. Karnataka India. 2014

9. Soekarto,Soewarno T.Penilaian Organoleptik
Untuk Industri Pangan dan Hasil Pertanian.,Pusbangtepa.1981

10. William J.boone.John R. Staver.,Melissa $\mathrm{S}$ Yale.Multifaceted Rasch Measurement .Dalam Rasch Analysis in The Human Sciences. hal. 426. Springer Science Business Media.2014

11. Lina Zuyana dan Merryana Adriani. Perbedaan Asupan Makan dan Status Gizi Pasien Hemodialisis Adekuat dan Inadekuat Penyakit Ginjal Kronik. Media Gizi indonesia, vol 9,No 1, Januari - Juni 2013

12. Stone H, Sidel JL. Sensory Evaluation Practice. Third edition. New York Academic Press. 2005

13. Bambang Sumintono \& Wahyu Widhiarso. Aplikasi Pemodelan RASCH Pada Assessment Pendidikan. Cimahi.Penerbit Trim Komunikata.2015

14. Maryam E, Zohreh M, Peyman J, Maryam A, Mohammad M. Major Barriers Responsible For Malnutrition in Hemodialysis Patient: Cahallanges Optimal Nutrition. Nephro Urol. 2014;23158 